\title{
UI EFEKTIVITAS EKSTRAK METHANOL DAUN BANGUN-BANGUN (COLEOUS AMBOINICUS) TERHADAP JAMUR CANDIDA ALBICAN
}

\author{
${ }^{1} \mathrm{M}$ Putri Diana $\mathbf{S}^{1}$ Elvia Annisa ${ }^{2}$ Maya Sari Mutia ${ }^{3}$ \\ 1,2,3Fakultas Kedokteran, Universitas Prima Indonesia,... \\ p_diana19@yahoo.com
}

\begin{abstract}
Abstrak :
Infeksi jamur Candida albican adalah pathogen yang sering dijumpai dan menginfeksi pada lingkungan sekitar karena jamur ini bersifat flora normal pada tubuh. Daun bangun-bangun (Coleus amboinicus) adalah tanaman yang sangat dikenal pada rakyat suku batak dengan memiliki kandungan flavoniod dan tannin. Pada penelitian ini bertujuan untuk mengetahui pengaruh daun bangun-bangun(Coleus amboinicus)terhadap pertumbuhan jamur Candida albicans dengan metode cakram pada suatu kelompok control, yaitu dilakukan dengan konsentrasi $20 \%, 40 \%, 60 \%, 80 \%$,dan $100 \%$. Pada hasil akhir penelitian menunjukkan zona hambat di ekstrak daun bangun-bangun (Coleus amboinicus) dengan konsentasi $20 \%, 40 \%, 60 \%, 80 \%$,dan $100 \%$. Zona hambat yang ditemukan adalah memilki rata-rata diameter $14,21,16,05,16,65,17,61$, dan 18,23 . Kesimpulan yang didapat pada rata-rata zona hambat menunjukkan perbedaan hasil setiap perlakuan konsentrasi, semakin besar konsentrasi ekstrak daun bangun-bangun maka semakin besar zona hambat pada Candida albican.
\end{abstract}

Kata kunci : Ekstrak daun bangun-bangun (Colous amboinicus), Candida albican

\section{The Efectiveness Test Of Coleous Amboinicus Leaves Extract Again Candida Albicans}

\begin{abstract}
:
Candida Albicans fungus infection is a pathogen that is often found and infects the surrounding environment because this fungus is a normal flora in the body. Leaves wake-up (Coleus amboinicus) is a plant that is well known to the Batak people with flavonoids and tannin content. This study aims to determine the effect of the leaves of wake-up (Coleus amboinicus) on the growth of the fungus Candida albicans by the disc method in a control group, which is done with a concentration of $20 \%, 40 \%, 60 \%, 80 \%$, and $100 \%$. In the final results of the study showed inhibition zones in the wake-up leaf extract (Coleus amboinicus) with concentrations of $20 \%, 40 \%, 60 \%, 80 \%$, and $100 \%$. Inhibited zones found were having an average diameter of $14.21,16.05,16.65,17.61$ and 18.23 . The conclusion obtained on the average inhibition zone shows the difference in the results of each treatment concentration, the greater the concentration of the wake-up leaf extract, the greater the inhibitory zone in Candida Albicans.
\end{abstract}

Keywords: Bangun-bangun leaf extract, Candida Albicans 


\section{PENDAHULUAN}

Kesehatan merupakan bagian terpenting bagi untuk menjadi makhluk sosial. Maka sebab itu kebersihan diri adalah aspek utama untuk dijaga.Dimulai dari kesehatan gigi dan mulut harus diperhatikan karena gerbang dari penyakit yang sering mempengaruhi kesehatan manusia ${ }^{(1)}$. Masyarakat Indonesia, masih cenderung mengabaikan kebersihan gigi dan mulut, padahal ketika sudah menjadi sakit akan mengganggu aktivitas itu sendiri, Penyakit gigi adalah penyakit yang sering dikeluhkan masyarakat di segala golongan, dan salah satu pathogen pada penyakit ini adalah Candida albican ${ }^{(2)}$

Salah satu tanaman terkenal di Suku Batak yaitu bangun-bangun (Coleus amboinicus) dimana bagian dari tanaman bangun-bangun yang sering dimanfaatkan adalah daun. Kandungan kimia dari daun ini seperti glikosida, flavonoid, tannin dan minyak atsiri $^{(3)}$ berkhasiat sebagai perangsang meningkatkan jumlah ASI (Laktogogum) dan mengobati penyakit lainnya, berupa batuk, demam, influenza, sakit kepala dan diare ${ }^{(4)}$.

Berdasarkan penjelasannya maka penelitian tentang tanaman ini perlu dilakukan uji efektivitas daun bangun-bangun (Coleus amboinicus) sebagai anti jamur. Diharapkan penelitian ini dijadikan refrensi pengobatan tanaman herbal untuk menanggulangi masalah kesehatan bagi masyarakat serta mengetahui dosis yang paling efektif dari ekstrat daun bangun bangun sebagai anti jamur ${ }^{(5)}$.

\section{METODE}

Metodologi pada penelitian ini adalah eksperimental laboratorik yang menggunakan difusi cakram rancangan Posttest Only Control Group Design. Penelitian ini dilakukan di bulan Agustus hingga bulan September tahun 2019 di Laboratorium Farmasi dan Toksologi Laboratorium Mikrobiologi Fakultas Kedokteran Universitas Prima Indonesia. Sampel dalam penelitia ini adalah Daun bangun-bangun (Coleus amboinicus) yang didapatkan di daerah jalan Pasar 3 dan jalan Central pasar Kota Medan serta biakan murni dari bakteri Candida albicans.

\section{Tahapan Penelitian}

\section{Sterilisasi alat}

Alat dan benda yang akan dipakai harus diatur dengan sedemikian rupa saat hendak dimasukkan ke dalam autoclave sehingga semua bagian alat dapat terkena uap secara merata dan juga menyeluruh dengan tekanan yang digunakan sebesar $1,5 \mathrm{~kg} / \mathrm{cm}^{2}$ di suhu 121 으 $C$ dengan waktu 15 menit menggunakan autoclave $^{(6)}$. Alat dan benda harus dibungkus untuk mencegah terjadinya rekontaminasi setelah keluar dari autoclave.

\section{Persiapan dan Pembuatan Sampel}

Daun bangun-bangun (Coleus amboinicus) didapatkan dari daerah Kota Medan jalan Pasar 3 dan Central pasar. Pembuatan sampel melalui beberapa proses yaitu pencucian, pemotongan, dan pengeringan. Pertama daun bangun-bangun (Coleus amboinicus) sebanyak $10 \mathrm{~kg}$ dicuci dahulu hingga bersih. Kedua dijemur selama 3 hari dengan suhu 40 ㄷ. Ketiga, daunnya yg kering di blender dengan kecepatan tinggi hingga berbentuk bubuk halus. Pada pembuatan ekstrak daun bangun-bangun (Coleus amboinicus) dilakukan maserasi menggunakan methanol, bubuk daun bangun-bangun (Coleus amboinicus) sebanyak $40 \mathrm{gr}$ dan $500 \mathrm{ml}$ methanol disetiap botol, dilakukan sebanyak 3 kali penyaringan dengan menggunakan kertas saring(7). Kemudian hasilnya dimasukkan ke rotary evaporator selama kurang lebih 20 jam untuk memisahkan methanol dari ekstrak sampai menjadi kental $^{(8)}$.

\section{Pembuatan Konsentrasi}

Pada ekstrak daun bangun-bangun (Coleus amboinicus) dicampur dengan ethanol 96\% dengan konsentrasi yang dibutuhkan. Dalam penelitian ini konsentrasi yang digunakan yaitu 20\%, 40\%, 60\%, 80\%, dan $100 \%(9)$. Rumus pengenceran konsentrasi $=x$ $100 \%$ sehingga apabila kita ingin mengencerkan ekstrak hingga 20\% maka yang diperlukan adalah 2 gram ekstrak dilarutkan dengan $10 \mathrm{ml}$ etanol 96\% untuk pelarut.

\section{Pembuatan Biakan Jamur}

Jamur yang digunakan pada penelitian ini didapati dari Laborartorium Farmasi USU. Candida albicans yang dibuat dari satu ose kuman biakan agar miring kemudian diletakan ke tabung yang berisi $\mathrm{NaCl}$, Aduk hingga seluruh koloni jamur homogen.

\section{Pembuatan Media Biakan}

Sebanyak 2 gram di suspensikan ke dalam 50 $\mathrm{ml}$ aquades ke dalam labu erlemeyer lalu diaduk dengan hot plate strirer selama hingga larut. Selanjutnya distrerilkan dengan autoclave di suhu 121 oC selama 15 menit, tunggu sampai suhunya 40-45으, selanjutnya agar langsung dituang ke dalam cawan petri lalu didinginkan hingga agar memadat ${ }^{(10)}$.

\section{Uji sensivitas}

Uji sensivitas dilakukan dengan cara ; Pertama, usapkan ke media PDA dengan menggunakan cotton swab, diamkan selama 10-15 menit. Lalu letakkan dan rendam blank disk di setiap konsentrasi ekstrak daun bangun bangun (Coleus amboinicus). Kemudian letakkan pada permukaan media agar yang 
berisi jamur dengan mengguanakan pinset. Setelah itu, inkubasi dalam suhu $3700 \mathrm{C}$ selama kurang lebih 48 jam. Terakhir periksa dan ukur zona hambat menggunakan jangka sorong.

HASIL

Diameter Zona Hambat Daun Bangun-bangun (Coleus amboinicus) terhadap jamur Candida albican

Efektivitas antijamur daun bangun-bangun (Coleus amboinicus) terhadap jamur Candida albican ditunjukkan dengan adanya zona hambat disekitar cakram. Didapati zona hambatzona hambat pada konsentrasi $20 \%, 40 \%, 60 \%, 80 \%$, dan $100 \%$ seperti tabel dan gambar dibawah ini

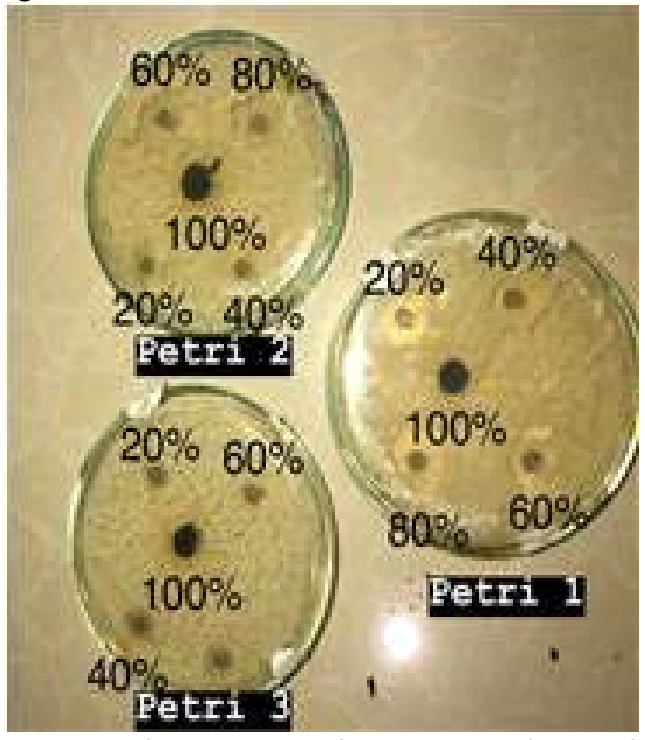

Gambar 1. Pengulangan 1,2, dan 3 dengan konsentrasi $20 \%, 40 \%, 60 \%, 80 \%$, dan $100 \%$ terhadap candida albicans

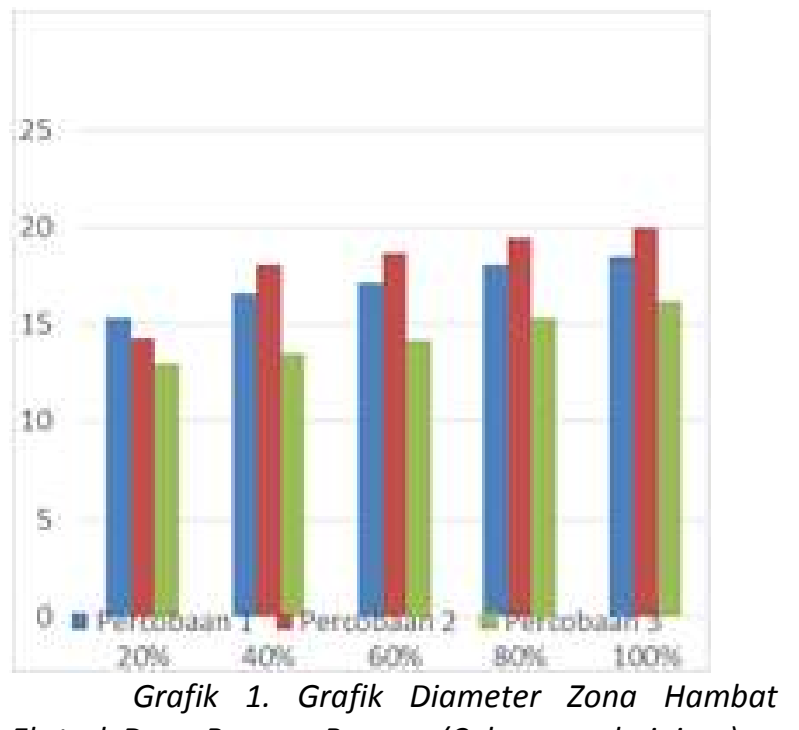

Ekstrak Daun Bangun-Bangun (Coleous amboinicus)
Tabel 1. Zona Hambat ekstrak daun bangun- bangun (Coleus amboinicus) terhadap jamur candida albican

\begin{tabular}{llllll}
\hline $\begin{array}{l}\text { Perco } \\
\text { baan }\end{array}$ & $100 \%$ & $80 \%$ & $60 \%$ & $40 \%$ & $20 \%$ \\
\end{tabular}

\begin{tabular}{lccccc}
\hline I & 18,5 & 18,1 & 17,1 & 16,6 & 16,01 \\
\hline II & 20 & 19,42 & 18,65 & 18,05 & 14,32 \\
\hline III & 16,2 & 15,3 & 14,2 & 13,5 & 13 \\
\hline Rata & 18,23 & 17,61 & 16,65 & 16,05 & 14,21 \\
\hline
\end{tabular}

Berdasarkan data di atas diperoleh hasil adanya daya hambat ekstrak daun bangun-bangun (Coleus ambboinicus) terhadap Candida albican yang diperoleh konsentrasi 20\%, 40\%, 60\%, 80\%, dan $100 \%$ pada perlakuan percobaan 1 , percobaan 2, percobaan 3. Rata- rata zona hambat pada konsentrasi $20 \%, 40 \%$, $60 \%$, $80 \%$, dan $100 \%$ berturut adalah $14,21 \mathrm{~mm}$, $16,05 \mathrm{~mm}, 16,65 \mathrm{~mm}, 17,6 \mathrm{~mm}$, dan 18,23mm. Rata-rata zona hambat paling kecil pada konsentrasi $20 \%$ yaitu $14,21 \mathrm{~mm}$. Rata-rata zona hambat paling besar pada konsentrasi $100 \%$ yaitu $18,2 \mathrm{~mm}$.

\section{DISKUSI}

Tabel 2. Klasifikasi Zona Hambat Greenwood

\begin{tabular}{ll}
\hline $\begin{array}{l}\text { Rata-rata Diameter } \\
\text { Zona Hambat }\end{array}$ & $\begin{array}{l}\text { Respon Hambatan } \\
\text { Pertumbuhan }\end{array}$ \\
\hline$>20 \mathrm{~mm}$ & Kuat \\
\hline $16-20 \mathrm{~mm}$ & Sedang \\
\hline $11-15 \mathrm{~mm}$ & Lemah \\
\hline$<10 \mathrm{~mm}$ & Tidak Ada \\
\hline \multicolumn{1}{c}{ Dari keempat konsentrasi ekstrak daun }
\end{tabular}
bangun bangun, konsentrasi $100 \%$ yang memiliki nilai rata-rata sebesar 18,23 merupakan kemampuan yang terkuat diantara kelima konsentrasi(12), namun tidak kuat untuk menghancurkan zona hambat candida albicans. Pada konsentrasi 40\%, 60\%, dan $80 \%$ memiliki nilai rata sebesar 16,05 mm, 16,65 mm, 17,6 $\mathrm{mm}$ merupakan konsentrasi yang sedang dan tidak mampu mencegah pertumbuhan total bakteri. Pada konsentrasi $20 \%$ memiliki nilai rata-rata sebesar 14,21 $\mathrm{mm}$ merupakan konsentrasi yang lemah untuk mengatasi pertumbuhan bakteri.

Bedasarkan hasil skrinning fitokimia pada ekstrak methanol daun bangun-bangun (coleous amboinicus) mengandung flavonoid, glikosida, dan 
saponin sebagai unsur utama di ekstrak tersebut. Pada umumnya, Flavonoid mampu disintesis oleh tanaman sebagai respon terhadap infeksi mikroba, kandungan flavonoid mampu sebagai anti jamur. Hal ini disebabkan adanya aktivitas dari kemampuan flavonoid yang membentuk ikatan protein terlarut yang menyebabkan membrane mikroba rusak.

Hasil zona hambat Greenwood di atas diketahui ekstrat daun bangun-bangun (Coleus amboinicus), hasil setiap konsentrasi berbeda sperti konsentrasi $20 \%$ memiliki kemampuan lemah, konsentrasi $40 \%$ memiliki kemampuan sedang, konsentrasi $60 \%$ memiliki kemampuan sedang, konsentrasi $80 \%$ memiliki kemampuan sedang dan konsentrasi $100 \%$ memiliki kemampuan sedang dalam dan ati ekstrat daun bangun-bangun (Coleus amboinicus), konsentrasi yang paling efektif dalam menghambat pertumbuhan jamur Candida albicans adalah konsentrasi $100 \%{ }^{(11)}$.

\section{SIMPULAN}

Berdasarkan hasil akhir penelitian yang telah dilakukan dalam uji efektivitas daun bangun-bangun (Coleus amboinicus) antijamur terhadap jamur Candida albican degan konsentrasi 20\%,40\%,60\%,80\%, dan $100 \%$ tidak efektiv dalam menghambat jamur Candida albican. Kemungkinan struktur senyawa pada daun bangun-bangun (Coleus amboinicus) tidak kuat dalam merusak bagian sel Candida albican tersebut.

\section{SARAN}

1. Disaranakan untuk melakukan penelitian lebih lanjut pada uji efektivitas ekstrak daun bangunbangun (Coleus amboinicus) dengan Candida albican dengan konsentrasi berbeda

2. Perlu dilakukan penelitian pada uji efektivitas ekstrak daun bangun bangun terhadap jamur lainnya.

3. Perlu penelitian lebih lanjut tentang unsur senyawa ekstrak daun bangun bangun (Coleus amboinicus)

\section{DAFTAR PUSTAKA}

1. Sari M, Suryani C. the Effect of Leaf Extract Starfruits ( Averrhoa Bilimbi L .) in. Pros Semin Nas Biol dan Pembelajarannya. 2014;05:325-32.

2. Fallis A. PERAN FAKTOR VIRULENSI PADA PATOGENESIS INFEKSI Candida albicans. J Chem Inf Model. 2013;53(9):1689-99.

3. Surya A, Jose C, Teruna HY. Studi Aktivitas Antioksidan Dari Ekstrak Metanol Dan Etil Asetat Pada Daun Bangun-Bangun. J IndCheActa. 2013;4(1):12-6.

4. Persentase LT, Dan K, Fisiologis O. PENGARUH PEMBERIAN EKSTRAK DAUN BANGUN-BANGUN ( Coleus. 2019;(January).

5. Kesehatan FI, Makassar UINA. ANTIMIKROBA EKSTRAK METANOL DAUN MIMBA. 2010;

6. Nuryanti S, Jura M, Nursucianti N. Uji Aktivitas Anti Jamur Ekstrak Kayu Manis (Cinnamomum Burmanii Blume) terhadap Jamur Candida Albicans. J Akad Kim. 2015;4(3):123-8.

7. DIANITA LAILA FAUZANA FAKULTAS TEKNOLOGI PERTANIAN PERCOLATION AND REPERCOLATION METHOD ON YIELD. 2010;

8. Kaye HL. Back to nature. Society. 2003;40(2):48-52.

9. Fati N, Siregar R, Lutfi UM. Pengaruh Pemberian Infusa Daun Bangun-Bangun (Coleus amboinicus, Lour) Terhadap Performa Broiler. J Livest Anim Heal. 2019;2(1):5-9.

10. Rakatama AS, Pramono A, Yulianti R. The Antifungal Inhibitory Concentration Effectiveness Test From Ethanol Seed Arabica Coffee (Coffea arabica) Extract Against The Growth Of Candida albicans Patient Isolate With In Vitro Method. J Phys Conf Ser. 2018;970(1)..

11. Tsui C, Kong EF, Jabra-Rizk MA. Pathogenesis of Candida albicans biofilm. Pathog Dis. 2016;74(4):ftw018. 